\title{
Article \\ Ownership Structure and Firm Performance in the Middle East: A Meta-Analysis
}

\author{
Yaseen Al-Janadi (iD \\ Department of Accounting and Information Systems, College of Business and Economic, Qatar University, \\ Doha P.O. Box 1327, Qatar; y.aljanadi@qu.edu.qa or yaseenjanadi@gmail.com
}

check for updates

Citation: Al-Janadi, Yaseen. 2021. Ownership Structure and Firm Performance in the Middle East: A Meta-Analysis. Journal of Risk and Financial Management 14: 577. https://doi.org/10.3390/ jrfm14120577

Academic Editor: Khaled Hussainey

Received: 30 September 2021

Accepted: 8 November 2021

Published: 1 December 2021

Publisher's Note: MDPI stays neutral with regard to jurisdictional claims in published maps and institutional affiliations.

Copyright: (C) 2021 by the author. Licensee MDPI, Basel, Switzerland. This article is an open access article distributed under the terms and conditions of the Creative Commons Attribution (CC BY) license (https:// creativecommons.org/licenses/by/ $4.0 /)$.

\begin{abstract}
This paper applies a meta-analysis method to investigate the moderating impact of political stability on the relationship between ownership identities and firm performance in the Middle Eastern countries (i.e., the Arab World). The study collected 105 correlations from 46 previous studies with 11,999 observations in 11 Middle Eastern countries. The findings show that most ownership identities such as institutional ownership, government ownership, inside ownership, and family ownership have positive relationship with firm performance. Another interesting finding shows that in countries with political instability, the level of ownership identities such as institutional ownership, foreign ownership, and inside ownership play an important role in controlling companies, which leads to firm performance. The meta-analysis results reveal that different levels of political stability have an impact on the role of the majority shareholders. The findings provide evidence that the performance of ownership identities in the Middle Eastern countries remains effective, especially with the existence of fair protection rights and political stability.
\end{abstract}

Keywords: ownership structure; firm performance; meta-analysis; political stability; Middle Eastern countries; institutional ownership; government ownership; foreign ownership; family ownership; inside ownership

\section{Introduction}

One of the substantial roles of a corporate governance system is the protection of stakeholders' investments. Creditors need to be reassured that they can receive returns from their finance (Shleifer and Vishny 1997), while shareholders strive for the protection of their investments. This striving usually takes three forms. First, the shareholders try to rely on a strong legal system that can protect their interests from exploitation of the management (Gillan 2006; Walsh and Seward 1990). Second, the shareholders delegate the board of directors as a protector of their wealth. If these two forms are weak in the protection of the shareholders' investments, the increase in the proportion of concentration ownership arises in order to enable shareholders to secure their wealth by directly influencing the management (Coffee 1991; Maug 1998).

La Porta et al. $(1998,2002)$ concluded that shareholders' rights to legal protection for countries (e.g., Spain and France) practicing civil law is usually inadequate, while the common law provides more reliable legal protection for shareholders. The civil law adopted in Middle Eastern countries is weak and unreliable, and thus does not provide sufficient shareholder protection rights (Bishara 2011). Furthermore, the political system in most of the Middle East is instable, which further contributes to weak legal protection. (Musibah 2017). Thereby, the shareholders in countries practicing civil law are required to play an active role in protecting their rights and wealth (Mangena et al. 2012). However, the role of shareholders in protecting their investments in the region of the Middle East is unknown. Subsequently, the current study investigates whether ownership concentration identities play a significant role in controlling companies in protecting their wealth in the Middle Eastern countries with inadequate legal and instable political systems. 
The argument regards the role of concentrated ownership in terms of competing, controlling, monitoring, and solving the agency problems (Shleifer and Vishny 1986) versus the companies' possession of resources which lead to a high risk of expropriation of minority shareholders (La Porta et al. 1999). The risk of conflict between large and small shareholders is exacerbated even more in emerging markets due to the weakness of protection regulation and the less developed institutions (Williamson 1991). However, the diversity of concentration among different groups leads to distribution of power among these groups (Jensen and Meckling 1976), which can be a remedy against the risk of conflict.

Conflicting theoretical arguments on the role of concentration ownership together with different kinds of identities of such concentration are accompanied by inconsistent results of empirical studies that have examined the relationship between the different types of ownership concentration and firm performance in Middle Eastern countries are one of the motivations for this paper. These inconsistent empirical results in Middle Eastern countries may be due to the diversity of populations, legal systems, types of sectors, or sampling errors. Additionally, the ambiguity of the theoretical and empirical predictors further motivated the present paper. Therefore, the current study aims to clarify the relationship of different types of ownership concentration with firm performance in the Middle Eastern countries. The findings will further help create a robust framework recognizing the role of ownership identities in Middle Eastern countries. Subsequently, this framework will be used by shareholders, policy makers, and the capital market. The framework will be most useful in developing countries, especially those with unstable political and incompetent legal systems.

The findings of the meta-analysis in this study show important results that can be generalized in developing countries, especially in those countries that have low political stability. These findings show that most types of ownership structure have a positive and significant association with firm performance. The findings also show that most of the types of ownership structure in non-financial companies play an important role in controlling companies other than financial companies. Another interesting result shows that, in the non-GCC countries which are characterized by political instability, the types of ownership structure play a more influential role in managing companies than in GCC countries. This role can enhance firm performance. On the contrary, in GCC countries which have political stability and strong government, government ownership has a stronger relationship with firm performance than in non-GCC countries.

The meta-analysis techniques employed in the current study are classified into two stages. The first stage is to investigate the direct relationship of each type of ownership concentration (institutional ownership, government ownership, foreign ownership, inside ownership, and family ownership) with firm performance. The second stage considers the type of sector and the geographical location as moderating for the direct ownershipperformance relationship. Meta-analysis techniques are used with a sample of empirical data from 46 studies that investigated the relationship between different types of ownership concentration and firm performance in 11 Middle Eastern countries.

The remainder of the paper is structured as follows: Section 2 presents the literature review and the development of the hypothesis. Section 3 discusses the methodology, which includes the selection of the sample and the procedures of the meta-analysis. Section 4 discusses the results, and Section 5 presents the conclusion and the proposed future research.

\section{Literature Review and Theoretical Background}

An old perception of ownership structure associated with an image of inefficiency suffers from various inherent inefficiencies such as the agency problem, underinvestment, and market failure (Chaddad and Cook 2004; Cook 1995; Grashuis and Su 2019). With the existence of the modern cooperation system, this perception, along with the concentration of ownership structure, has varied from region to region. For example, the Anglo-Saxon countries enjoy ownership diffusion (Lefort and Urzúa 2008) while concentrated ownership seems to be commonly practiced in most Asian and Arab countries (Denis and McConnell 
2003; Heugens et al. 2009) and to some extent, European countries such as France, Germany, and the Scandinavian countries (La Porta et al. 1999).

The concentrated ownership comprises different categories. The diversity of concentration may include several priorities and preferences related to stability, risk, and performance (Douma et al. 2006). Several views are involved in the argument of the diversity of ownership concentration. According to Jensen et al., the diversity of ownership concentration can be distributed between different groups of shareholders (Jensen and Warner 1988), However, Morck and his colleagues claim that the diversity of ownership concentration can create conflict control among shareholder groups (Morck et al. 2005). Thus, this study attempts to examine most of the popular types of ownership concentration such institutional, government, foreign, inside, and family ownership.

\subsection{Ownership Concentration and Firm Performance}

The arguments in the body of literature concerning the performance of ownership concentration can be divided into positive and negative relationships with the weight of positive view. The positive view in the literature was originally initiated by the argument of Agency Theory. It indicates that ownership concentration can mitigate the agency problem between management and ownership by directly influencing the management to protect the interest of shareholders (Shleifer and Vishny 1986). This influence can reduce the cost associated with the conflict of interest between ownership and management (Eisenhardt 1989). Others claim that the high level of concentrated ownership, especially with fewer block-holders, boosts their power to fully monitor the management decisions towards maximizing performance (Zeckhauser and Pound 1990). Based on the Resource Dependence Theory perspective, the owners with a high proportion of the concentration can use their connections in providing sufficient resources (Carney and Gedajlovic 2001) and thus support and control the management (Pfeffer and Salancik 2003). In developing countries where the legal system is inadequate (Gillan 2006), investors have no choice but to admit their involvement in the management control. Therefore, concentrated ownership is the tool that owners can use to practice the influence on management by engaging in the governance and accessing directly to create strategies (Claessens et al. 2006).

On the negative view of the relationship between concentrated ownership and performance, La Porta argue that the concentrated owners try to possess the resources (i.e., assets and profits) of the company for the benefit of themselves at the expense of the minority of shareholders. This could lead to the expropriation of the minority shareholders (La Porta et al. 1999). Accordingly, this negative view has an influence at the high level of ownership concentration, which can, in turn, affect the company performance owing to the high risk that companies may encounter.

The relationship between ownership concentration and firm performance has been examined in most of the Middle Eastern countries. The results of the empirical studies from these countries are inconclusive. While some authors reported a significant negative relationship between ownership concentration and firm performance (e.g., Abdelkarim and Alawneh 2009; Al-Saidi and Al-Shammari 2013; Arayssi and Jizi 2018; Hamdan 2018), others reported a positive relationship (e.g., Abdallah and Ismail 2017; Aktan et al. 2018; Al-Smadi 2013). Therefore, the study formulates the following hypothesis:

Hypothesis 1. There is a positive relationship between concentrated ownership and firm performance.

\subsection{Institutional Ownership}

Institutional investors can play a substantial role in the financial market. They are particularly efficient in monitoring management due to their large incentive of monitoring (Grossman and Hart 1980). They have also better expertise, strong power, and analytical knowledge. The cost of monitoring is high; thus, practicing monitoring by institutional investors will reduce the cost of monitoring which will result in enhancing the firm performance (Almazan et al. 2005). Furthermore, on the basis of Resource Dependence Theory, 
institutional investors provide more resources to the company so as to increase the firm performance (Shleifer and Vishny 1986).

On the contrary, McConnell and Servaes (1990) state that institutional owners have a negative impact on the firm performance due to a potential conflict of interest. This conflict is attributed to the profitable deals made by the management of the company, which force the institutional investors to voting shares. This type of conflict makes the monitoring role of the institutional investors ineffective. Another disadvantage is that the strategic alignment between institutional investors and management can bring about mutual cooperation between the two parties (Agrawal and Knoeber 1996). Similarly, Maug notes that the influence of institutional investors towards efficient firm performance relies on the size of their ownership (Maug 1998). If the proportion of institutional shareholdings is low, the incentive for monitoring will be less as they can liquidate their shares easily when the company has poor performance. On the other hand, if the proportion of the institutional ownership is high, firm performance will be more efficient. Therefore, most Middle Eastern countries are characterized by having a high proportion of institutional ownership, for example: 34\% in Saudi-listed companies (Amin and Hamdan 2018), 22\% in Omani-listed companies (Al-Matari et al. 2017), 56\% in Omani non-financial listed companies (Yilmaz 2018), 39\% in the non-financial listed companies for the six GCC countries (Zeitun 2014), and 36\% in Egyptian-listed companies (Elsayed 2007). As Maug (1998) argues, the high proportion of institutional ownership in the Middle East countries may have more positive impact on firm performance.

Empirical studies conducted in Middle Eastern countries support Maug's (1998) argument. Furthermore, the results of numerous empirical studies performed in the Middle East show that institutional ownership practice reveals an efficient positive relationship with firm performance (e.g., Al-Smadi 2013; Amin and Hamdan 2018; Arouri et al. 2014; Elsayed 2007; Hamdan 2018). However, there are several empirical studies which display a negative relationship between institutional ownership and firm performance (e.g., Al-Matari et al. 2017) from Omani companies (e.g., Zeitun 2014) from non-financial companies in GCC countries. The mixed results from the Middle Eastern countries studied and the different theoretical arguments concerning the role of institutional ownership towards firm performance suggest formulating the following hypothesis:

Hypothesis 2. There is a positive relationship between institutional ownership and firm performance.

\subsection{Government Ownership}

Ownership structure has become an essential component of economic development. The active market, such as the Anglo-American market, is characterized by a focus on separating ownership from control (Luo 2007). As Piesse et al. (2012) state, the active market with an effective corporate control is distinguished by having a low level of family and government ownership. On the contrary, the markets of most Middle Eastern countries are considered to be at a high level of concentrated ownership, especially government and family ownership (Al-Janadi et al. 2016; Fallatah 2015). Such a level of government ownership gives a prediction that ownership concentration may contradict effective corporate control, which leads to firm performance.

Government ownership is one of the most significant variables of ownership structure which has an impact on the economic consequences of the companies such as financial performance (Haider et al. 2018). Governments practicing their political power in companies can create conflicts of interest with a minority of shareholders. Yu and Shao (2007) state that most Chinese-listed companies controlled by government ownership, with directly political goals in mind, have contributed to weakening the protection of the minority shareholders. Another argument based on Priority Right Theory is that government ownership has a negative impact on the firm performance because the governments focus on social welfare at the expense of firm performance (Al-Malkawi and Pillai 2018; Laffont and Tirole 1991). 
Another perspective is that government ownership may lead to increased financial performance. Based on Resource Dependence Theory, government ownership can participate in reducing the cost of capital because governments have more capability in providing financial and qualified human resources to enhance the firm performance (Pfeffer and Salancik 2003). Notably, human capital and knowledge of the board of directors may have an impact on providing efficient resource allocation (Hillman and Dalziel 2003). Furthermore, it was argued that government ownership can improve corporate-governance best practices and consequently firm performance because governments can use their coercive power to provide effective monitoring and direct enforcement (Al-Janadi et al. 2016). The power of intervention will increase if the companies are owned by the governments (Boycko et al. 1996). For example, GCC countries are characterized by having most of their listed companies owned by either governments or families (Al-Janadi et al. 2016).

Empirical evidence on the association between government ownership and financial performance in Middle Eastern countries seems to be inconclusive. For instance, empirical studies show that there is a negative relationship between government ownership and financial performance (e.g., Al-Malkawi and Pillai 2018; Alawi 2019; Zeitun and Tian 2007). However, other studies have revealed a positive relationship (e.g., Abdallah and Ismail 2017; Al-Matari et al. 2017; Zeitun 2014). Therefore, the current study formulates the following hypothesis:

Hypothesis 3. There is a positive relationship between government ownership and firm performance.

\subsection{Foreign Ownership}

The attraction of foreign investments is important especially in developing countries such as Middle Eastern countries because foreign ownership provides new capital and technologies in order for local companies to become world class. Based on the perspective of Resource Dependence Theory as discussed by Benfratello and Sembenelli (2002) and Pfeffer and Salancik (2003), foreign ownership is considered to be one of the main supplying resources to the markets, especially in developing countries, because it provides new capital and technology. This, in turn, can lead to increased firm performance. Another perspective on foreign ownership is that foreigners are not familiar with the environment they invest in. This, of course, can lead to poor firm performance (Barbosa and Louri 2005).

Foreign investment in Middle Eastern countries is still at a very low level because there is no clear policy of attracting foreign investment. For example, the Saudi market was not open for foreign investment until 2015 when the Saudi government allowed foreigners to invest in specific sectors (Amin and Hamdan 2018). The results of empirical literature from Middle Eastern countries are inconsistent. Some empirical studies found a negative relationship between foreign ownership and firm performance (e.g., Amin and Hamdan 2018; Elghuweel et al. 2017; Talab et al. 2018). Other empirical studies suggest a positive relationship between foreign ownership and firm performance (e.g., Abdallah and Ismail 2017; Al-Matari et al. 2017; Zraiq and Fadzil 2018). Accordingly, the current study formulates the hypothesis as follows:

Hypothesis 4. There is a positive relationship between foreign ownership and firm performance.

\subsection{Insider Ownership}

The board of directors or executive managers can perform better towards firm performance when they are shareholders. According to Agency Theory, insider shareholders reduce the agency cost due to sharing the common interest with outside shareholders (Jensen and Meckling 1976).

On the other hand, managerial ownership can negatively influence the firm performance owing to the impediment of the efficiency of the board of directors in terms of practicing internal control, particularly in the countries that have weak legal protection, i.e., Middle Eastern countries (Denis and Denis 1994; Morck et al. 1988). Furthermore, 
increasing managerial ownership can lead shareholders to expropriate the minority shareholders' wealth (Fama and Jensen 1983). The theoretical difference in the inside ownershipperformance results in differences in the empirical studies conducted in Middle Eastern countries. While some researchers have found a positive relationship between inside ownership and performance (e.g., Al-Malkawi and Pillai 2018; Elsayed 2007; Talab et al. 2018), others found a negative relationship (e.g., Al-Matari and Al-Arussi 2016; Basuony et al. 2014). Therefore, the study formulates the following hypothesis:

Hypothesis 5. There is a positive relationship between inside ownership and firm performance.

\subsection{Family Ownership}

The theoretical literature regarding the relationship between family ownership and firm performance has been divided into positive and negative views. On the positive side, the family ownership as concentrated ownership has the desire and power to control and monitor the management efficiently (Demsetz and Lehn 1985; Shleifer and Vishny 1986). Such control has been seen to be stronger in developing countries such as Middle Eastern countries due to the weak existence of institutional ownership. As a result, family ownership is brought as an alternative for providing efficient control of the management (Wang and Shailer 2017), which leads to an increase in the corporate performance (Anderson and Reeb 2003). Based on Agency Theory, family ownership can mitigate the agency problem, especially in developing countries, by engaging family members in the management of the companies and, thus, enhancing the corporate performance (Bocatto et al. 2010).

The negative side of family ownership states that family ownership as block-holders gives priority for their interest at the expense of other shareholders' interest (Morck et al. 1988). Thus, the agency problem exists on the conflict of interests, not only between shareholders and managers but also between the majority (i.e., family ownership) and the minority shareholders (Santiago-Castro and Brown 2007). The other argument is that family ownership tries to get involved in the selection of management where nepotism in the selection process may dominate in both controlling and monitoring the management (Claessens et al. 2002).This, indeed, will affect firm performance (Smith and Amoako-Adu 1999). For instance, when the important rights of cash follow are in the hands of family ownership, they use these rights for the benefit of their family members at the expense of corporate performance (Arouri et al. 2014).

In regard to the proportion of family ownership, Middle Eastern countries appear to be high because most of the listed companies were family owned before they had been converted into listed companies. For example, Zraiq and Fadzil (2018) state that the proportion of listed Jordanian family-owned companies is more than $46 \%$. Al-Ghamdi and Rhodes (2015) found that $56 \%$ of Saudi-listed companies are family owned. In the same line, Smith (2009) found that 75\% of GCC-listed companies are dominated by family ownership. On the other hand, most Middle Eastern countries, excluding Jordan, do not reveal data on the family ownership. For example, Almudehki and Zeitun (2012) state that Qatari-listed companies do not have available data about the family ownership. Additionally, Khamis et al. (2015) found that Bahrain-listed companies do not have enough data on the family ownership. Thus, only a few studies from Middle Eastern countries examined the impact of family ownership on firm performance. Some studies examined family ownership in Middle Eastern countries and found a positive relationship (e.g., Arouri et al. 2014; Amin and Hamdan 2018; Charbel et al. 2013; Al-Saidi and Al-Shammari 2015). However, a few studies found a negative relationship between family ownership and firm performance (e.g., Jaafar and El-Shawa 2009; Mohammed 2018). Consequently, the current study formulates the following hypothesis:

Hypothesis 6. There is a positive relationship between family ownership and firm performance. 


\section{Moderating Variables}

\subsection{Geographical Location}

The Arab countries in the Middle East share common characteristics, such as language, religion, culture, race, and ethnicity. These states are recognized as developing countries with emerging market economies. From a geo-economic and political point of view, Middle Eastern countries can be categorized into two types. Gulf Cooperation Council countries (GCC), which differ from other Middle Eastern countries in terms of political and financial stability. The GCC countries depend heavily on oil production and, thus, have a higher income than non-GCC countries. Furthermore, all GCC countries are monarchy states while non-GCC countries are republican states, except for Jordan and Morocco. Another difference is that GCC states are politically stable and socially homogeneous while nonGCC states are socially and politically unstable. As a result of political and economic instability, shareholders strenuously strive to protect theirs investments (Mangena et al. 2012; Musibah 2017). Thus, there is expectation that the ownership structure identities practice a stronger role of control in non-GCC countries than GCC countries, which reflects the level of firm performance.

\subsection{Industry Type}

The differences in the industry types may have a moderating impact on the association between ownership concentration identities and firm performance thanks to the accounting and regulating policies in the financial institutions, which seem to be stronger than in nonfinancial organizations. According to Dalwai et al. (2015), the regulation of the financial sector in GCC, such as the corporate governance system, has been implemented differently to the non-financial sector. Such a difference may result in a different role of large shareholders. Shleifer and Vishny (1997) state that the effective role of large shareholders depends on the background of the companies and the quality of the legal system. Heugens et al. (2009) conducted a study in which he found that the background of the institution has a significant impact on the role of majority shareholders. Thus, the current study expects that the relationship between ownership concentration identity and firm performance is different for financial companies and non-financial companies.

\section{Methodology}

\subsection{Data Collection}

The search strategy in the reviewed articles is to recognize all relevant published or unpublished research in English. The process of reviewing all relevant articles has undergone several steps. First, several databases were used including Google Scholar, Elsevier, Emerald, JSTOR, Springer, ProQuest, and EBSCO to search for the terms related to ownership structure and its types in the Arabic countries of the Middle East with firm performance. For example, searching for different combinations of the term "ownership concentration" with the term "Middle East" is swapping with other types of ownership structure and with each country in the Middle East or GCC. For the term "corporate governance", some studies dealt with ownership structure in their investigation as one component of corporate governance. Second, the references of all studies obtained in the first step were again examined to find related studies. Furthermore, Google Scholar is also used to search for citations of the original papers. Studies that are not relevant to the measurements used in this study were omitted. For example, studies such as Shawtari (2018), who measured the ownership concentration using a dichotomous method in which is ' 1 ' yes and ' 0 ' otherwise, were omitted. In addition, Al-Ghamdi and Rhodes (2015) both measured the family ownership in Saudi-listed companies by categorizing all listed companies into family firms and non-family firms. The present study selects only the reviewed studies which used an accounting-based measurement that has returns on assets (ROA) as the firm performance measurement. Selecting the ROA was based on the fact that that most of the reviewed studies have used ROA as firm performance measurement. Furthermore, using the ROA method is an effective and accurate tool to measure the profit 
of the companies derived from the capital assets in which companies invest (Epps and Cereola 2008). Thus, after omitting the inappropriate studies, the final sample consists of 46 empirical studies, yielding 11,999 samples.

\subsection{Meta-Analysis Procedures}

The meta-analysis method has been widely used (Hunter and Schmidt 2004) as it provides accurate techniques in both analysis and management of the conflict results of the previous studies. In this study, the meta-analysis method is used to analyze the results of previous empirical studies in a statistical systematic technique. Specifically, in metaanalysis, the different results of previous studies are aggregated and transformed into one common measurement called the effect size. This technique facilitates the comparison between the effect size results and measures the magnitude of the true relationship between the independent variable (i.e., ownership concentration) and the dependent variable, namely the firm performance in this study. Based on the method of Hedges and Olkin (1985), the effect size is represented by the Pearson correlation coefficient " $r$ " for each individual empirical study included in the sample, where " $r$ " examines the direct relationship between tow variables and free of scale from any linear relationships. Following the formula suggested by Hunter and Schmidt (2004) and Cooper et al. (2019), we aimed to transform the result of the $t$-test or $z$-test into $r$. The correlation coefficient " $r$ " is statistically used for each variable included in the analysis of the current study. If the " $r$ " is not reported in the reviewed study, yet the $t$-test or $z$-test of the regressions result is reported, then these tests are converted into " $r$ ". The formula is illustrated as follows:

$$
r=\frac{\mathrm{t}}{\sqrt{\mathrm{t}^{2}+\mathrm{df}}} \quad r=\frac{\mathrm{Z}}{\sqrt{N}}
$$

The second step after computing the effect size for all reported studies is to transform the coefficient correlation into Fisher's z correlation, using Fisher's Zr to remedy the skewness of the distribution of the effect size to be normal. The formula presented by Borenstein et al. (2009) $Z=0.5 \log \frac{\left(1+r_{i}\right)}{\left(1-r_{i}\right)}$.

The standard errors (SEs) are also calculated to describe the variability of the sample distribution in the relationship between the interested variables. Including the SEs in the meta-analysis is very important to quantify the precision of the effect size (Ellis 2010). The smaller the $\mathrm{SE}$, the more precise the effect size. $\mathrm{SE}=\frac{1}{\sqrt{\mathrm{N}-3}}$.

The next step is to evaluate the homogenous correlation for the relationship between the variables. The $Q$ test and the $\mathrm{I}^{2}$ test are used to examine the homogeneity. The $Q$ test is the most common test used to assess the true heterogeneity test in meta-analysis studies (Cochran 1954; Heugens et al. 2009). The $\mathrm{I}^{2}$ test describes the percentage of variation of the effect sizes across the entire sample due to heterogeneity rather than chance.

$$
\mathrm{I}^{2}=\left(\frac{Q-d f}{Q}\right) \times 100 \%
$$

Two meta-analysis models have been commonly used in most of the previous metaanalysis studies: the random-effect model and the fixed-effect model. The random effect size model is used to synthesize the value of the effect size. This model presents realistic and logical results and answers the research questions more accurately than the fixedeffect model. The preference of random-effect model is due to the consideration of the variance for the sample size across reported studies where the fixed effect model assume the sample size of all reported studies is constant (Kisamore and Brannick 2008). Therefore, the fixed effect model is preferably used in case there is homogeneity of variance in the correlation results. 


\section{Results and Discussion}

The study conducted meta-analysis method to find out the relationship between the ownership structure variables and firm performance in Middle Eastern countries using 46 studies. Table 1 presents the details of the reviewed studies including the country, number of observations, sector, and the Pearson coefficient of the correlation between the concentrated ownership identities and firm performance. First, the Results and Discussion section provides the meta-analysis results to find out the effect size of the relationship between ownership structure variables and firm performance. Second, if the general metaanalysis results find a high level of heterogeneity, the sub-groups of meta-analysis test are conducted for the moderating factors.

Table 2 summarizes the results of the meta-analysis association between the ownership structure variables and firm performance, utilizing the random effect size model, while Table 3 summarizes the result of the same relationship, utilizing the fixed-effects model. The overall results in both models show that most of ownership structure variables have a positive relationship with firm performance, except for foreign ownership and concentrated ownership.

\subsection{Ownership Concentration}

The results on the relationship between ownership concentration and corporate performance were reported for 31 studies. Table 2 indicates that this relationship is not significant, with the mean of the effect size being $0.00232(Z=0.0720 ; P 0.943)$. The $95 \%$ confidence interval $(-0.061 / 0.066)$ includes zero, which confirms an insignificant relationship. As noted in the raw correlation coefficient value of the studies, there are differences in the values between high negative coefficient results compared to high positive coefficient results. This result shows that there is no significant relationship. Such a large discrepancy in the results was confirmed by the results of the $Q$ test $(261.030 ; p<0.001)$ and the $I^{2}$ test $(87.65 \%)$, which indicate that there is a high level of heterogeneity across studies. Therefore, there is a need to conduct further tests to reduce the level of heterogeneity and investigate the possibility of influencing the moderating factors on the direct relationship between ownership concentration and firm performance. The study conducted subgroups of meta-analysis on three types of moderating factors including the concentrated ownership, geographical location, and sector. 
Table 1. Details of reviewed studies.

\begin{tabular}{|c|c|c|c|c|c|c|c|c|c|c|}
\hline Study & Country & $\begin{array}{c}\text { No. of } \\
\text { Observation }\end{array}$ & Sector & Concentrated & Institutional & Governmental & Foreign & Inside & Family & Type of Concentration \\
\hline Sarhan et al. (2018) & Middle E. & 494 & Non-Fin & 0.258 & 0.165 & 0.046 & & & & $5 \%$ and more \\
\hline Al-Shammari and Al-Sultan (2009) & Kuwait & 264 & Non-Fin & 0.027 & & & & & & $5 \%$ and more \\
\hline Al-Saidi and Al-Shammari (2013) & Kuwait & 45 & Financial & -0.200 & & & & & & $5 \%$ and more \\
\hline Fallatah (2015) & Saudi A. & 455 & Non-Fin & & & 0.387 & & & & Yes or No \\
\hline Abobakr (2017) & Egypt & 188 & Financial & -0.248 & & & & & & $5 \%$ and more \\
\hline Zeitun (2014) & GCC & 1053 & Non-Fin & 0.105 & -0.027 & 0.110 & -0.027 & & & Largest5 \\
\hline Elsayed (2007) & Egypt & 361 & Listed & & 0.163 & & & 0.122 & & \\
\hline Basuony et al. (2014) & Middle E. & 50 & Financial & -0.453 & & & & -0.128 & & $5 \%$ and more \\
\hline Al-Saidi and Al-Shammari (2015) & Kuwait & 618 & Non-Fin & & & 0.066 & & & 0.093 & \\
\hline Almudehki and Zeitun (2012) & Qatar & 138 & Non-Fin & 0.253 & -0.035 & & -0.016 & & & Largest5 \\
\hline Arouri et al. (2011) & GCC & 27 & Financial & -0.471 & -0.076 & & -0.156 & & & $5 \%$ and more \\
\hline AlSagr et al. (2018) & Saudi A. & 54 & Financial & -0.335 & & & 0.195 & & & Largest3 \\
\hline Yilmaz (2018) & Oman & 244 & Non-Fin & -0.079 & 0.077 & & & & & score $1-10$ \\
\hline Hamdan (2018) & Saudi A. & 131 & Listed & -0.076 & 0.025 & & & & & $5 \%$ and more \\
\hline Makhlouf et al. (2017) & Jordan & 500 & Non-Fin & & & & & 0.162 & & \\
\hline Aktan et al. (2018) & Bahrain & 90 & Financial & 0.290 & & & & & & $5 \%$ and more \\
\hline Talab et al. (2018) & Iraq & 276 & Listed & 0.076 & & & -0.332 & 0.171 & & largest one \\
\hline Arayssi and Jizi (2018) & Middle E. & 158 & Listed & 0.031 & & & & & & special charact \\
\hline Jaafar and El-Shawa (2009) & Jordan & 396 & Non-Fin & -0.025 & 0.049 & 0.025 & & & -0.022 & $5 \%$ and more \\
\hline Soliman (2013) & Saudi & 192 & Non-Fin & 0.203 & & & & & & $\%$ owned by large \\
\hline Khamis et al. (2015) & Bahrain & 210 & Listed & -0.138 & -0.019 & & -0.052 & 0.027 & & $\% 1 / \% 5$ \\
\hline Khamis et al. (2015) & Bahrain & 210 & Listed & & -0.019 & & & & & \\
\hline Qasim and Mohammad (2014) & UAE & 281 & Listed & & 0.122 & 0.041 & & & & \\
\hline Jadah et al. (2016) & Iraq & 180 & Financial & & 0.047 & & & 0.776 & 0.131 & \\
\hline Khamis et al. (2015) & Bahrain & 42 & Listed & -0.302 & 0.299 & & & & & Largest5 \\
\hline Zeitun and Tian (2007) & Jordan & 165 & Non-Fin & 0.160 & 0.055 & 0.046 & -0.008 & & & Largest5 \\
\hline Amin and Hamdan (2018) & Saudi A. & 171 & Listed & 0.075 & 0.149 & & -0.179 & 0.124 & & Largest3 \\
\hline
\end{tabular}


Table 1. Cont.

\begin{tabular}{|c|c|c|c|c|c|c|c|c|c|c|}
\hline Study & Country & $\begin{array}{c}\text { No. of } \\
\text { Observation }\end{array}$ & Sector & Concentrated & Institutional & Governmental & Foreign & Inside & Family & Type of Concentration \\
\hline Eljelly (2009) & Saudi A. & 279 & Listed & & & 0.221 & & & & \\
\hline Al-Shiab and Abu-Tapanjeh (2005) & Jordan & 388 & Non-Fin & 0.018 & 0.091 & -0.028 & -0.041 & & & $10 \%$ and more \\
\hline Al-Saidi (2013) & Kuwait & 520 & Non-Fin & 0.140 & 0.040 & 0.070 & & & 0.110 & $5 \%$ and more \\
\hline AlAni and AlKathiri (2019) & Oman & 575 & Financial & -0.214 & & & -0.251 & & & Omani shareholders \\
\hline Abu-Serdaneh et al. (2010) & Jordan & 280 & Non-Fin & -0.135 & 0.119 & & -0.027 & -0.015 & & $10 \%$ and more \\
\hline Charbel et al. (2013) & Lebanon & 75 & Listed & & & & & & 0.695 & \\
\hline Al-Matari and Al-Arussi (2016) & Oman & 243 & Non-Fin & 0.076 & & 0.275 & & -0.064 & & Largest5 \\
\hline Mohammed (2018) & Jordan & 58 & Listed & -0.113 & & & & & & $5 \%$ and more \\
\hline Zraiq and Fadzil (2018) & Jordan & 228 & Non-Fin & & & & 0.114 & & 0.141 & \\
\hline Alfaraih et al. (2012) & Kuwait & 134 & Non-Fin & & 0.202 & -0.077 & & & & \\
\hline Dwaikat and Queiri (2014) & Palestine & 31 & Listed & -0.413 & & & & 0.534 & & $5 \%$ and more \\
\hline Al-Smadi (2013) & Saudi & 55 & Financial & 0.173 & 0.358 & & 0.076 & & & $5 \%$ and more \\
\hline Elghuweel et al. (2017) & Oman & 1160 & Listed & -0.114 & 0.024 & 0.207 & -0.041 & & & $5 \%$ and more \\
\hline Zeitun (2012) & GCC & 219 & \multicolumn{2}{|c|}{ Financial } & & & 0.020 & & & \\
\hline Alawi (2019) & Saudi A. & 171 & Listed & & -0.134 & -0.474 & -0.040 & & & \\
\hline El-Chaarani (2014) & Lebanon & 182 & Financial & 0.532 & & & & 0.604 & & largest one \\
\hline Desoky and Mousa (2013) & Egypt & 99 & Non-Fin & & -0.133 & 0.110 & & & & \\
\hline
\end{tabular}


Table 2. Results of variables with moderating variables-Fisher-z correlation coefficient.

\begin{tabular}{|c|c|c|c|c|c|c|c|c|c|c|c|}
\hline & & $\%$ & Estimate & se & $\mathbf{Z}$ & $\mathbf{p}$ & CI Lower Bound & CI Upper Bound & $\mathrm{I}^{2}$ & $\mathbf{Q}$ & $\mathbf{P}$ \\
\hline Ownership Concentration & 30 & $50 \%$ & -0.00374 & 0.0350 & -0.107 & 0.915 & -0.072 & 0.065 & $87.75 \%$ & 253.094 & $<0.001$ \\
\hline \multicolumn{12}{|l|}{ Type of Concentration } \\
\hline $\begin{array}{l}\text { Ownership concentration with 5\% } \\
\text { and more }\end{array}$ & 18 & & -0.0483 & 0.0437 & -1.10 & 0.270 & -0.134 & 0.037 & 86.76 & 144.052 & \\
\hline Largest 3, 5, 10 shareholders & 11 & & 0.0843 & 0.0522 & 1.61 & 0.106 & -0.018 & 0.187 & 83.31 & 73.112 & \\
\hline \multicolumn{12}{|l|}{ Countries } \\
\hline Other Middle Eastern countries & 12 & & 0.000495 & 0.0660 & 0.00895 & 0.993 & -0.129 & 0.130 & $90.31 \%$ & 128.233 & $<0.001$ \\
\hline GCC & 18 & & -0.00804 & 0.0387 & -0.207 & 0.836 & -0.084 & 0.068 & $83.57 \%$ & 117.068 & $<0.001$ \\
\hline \multicolumn{12}{|l|}{ Sector } \\
\hline Financial Sector & 9 & & -0.0890 & 0.112 & -0.794 & 0.427 & -0.309 & 0.131 & $91.71 \%$ & 129.817 & $<0.001$ \\
\hline Non-Financial & 12 & & 0.0818 & 0.0328 & 2.49 & 0.013 & 0.018 & 0.146 & $76.62 \%$ & 52.958 & $<0.001$ \\
\hline All listed & 9 & & -0.0634 & 0.0369 & -1.72 & 0.086 & -0.136 & 0.009 & $49.43 \%$ & 20.386 & 0.009 \\
\hline Institutional Ownership & 24 & $37.33 \%$ & 0.0572 & 0.0183 & 3.13 & 0.002 & 0.021 & 0.093 & $49.36 \%$ & 48.320 & 0.002 \\
\hline \multicolumn{12}{|l|}{ Country } \\
\hline Non GCC & 8 & & 0.0944 & 0.0246 & 3.84 & $<.001$ & 0.046 & 0.143 & $25.85 \%$ & 10.868 & 0.144 \\
\hline \multicolumn{12}{|l|}{ Sector } \\
\hline Financial Sector & 3 & & 0.121 & 0.0890 & 1.36 & 0.174 & -0.053 & 0.295 & $33.19 \%$ & 5.163 & 0.076 \\
\hline Non-Financial & 12 & & 0.0539 & 0.0230 & 2.34 & 0.019 & 0.009 & 0.099 & $47.52 \%$ & 23.429 & 0.015 \\
\hline All listed & 9 & & 0.0611 & 0.0287 & 2.13 & 0.033 & 0.005 & 0.117 & $39.21 \%$ & 15.835 & 0.045 \\
\hline Government ownership & 16 & $14 \%$ & 0.0871 & 0.0392 & 2.22 & 0.026 & 0.010 & 0.164 & $89.4 \%$ & 155.690 & $<0.001$ \\
\hline \multicolumn{12}{|l|}{ Country } \\
\hline Non-GCC & 5 & & 0.0261 & 0.0256 & 1.01 & 0.307 & -0.024 & 0.076 & $0 \%$ & 2.049 & 0.727 \\
\hline GCC & 11 & & 0.108 & 0.0504 & 2.15 & 0.032 & 0.009 & 0.207 & $91.61 \%$ & 137.550 & $<0.001$ \\
\hline
\end{tabular}


Table 2. Cont.

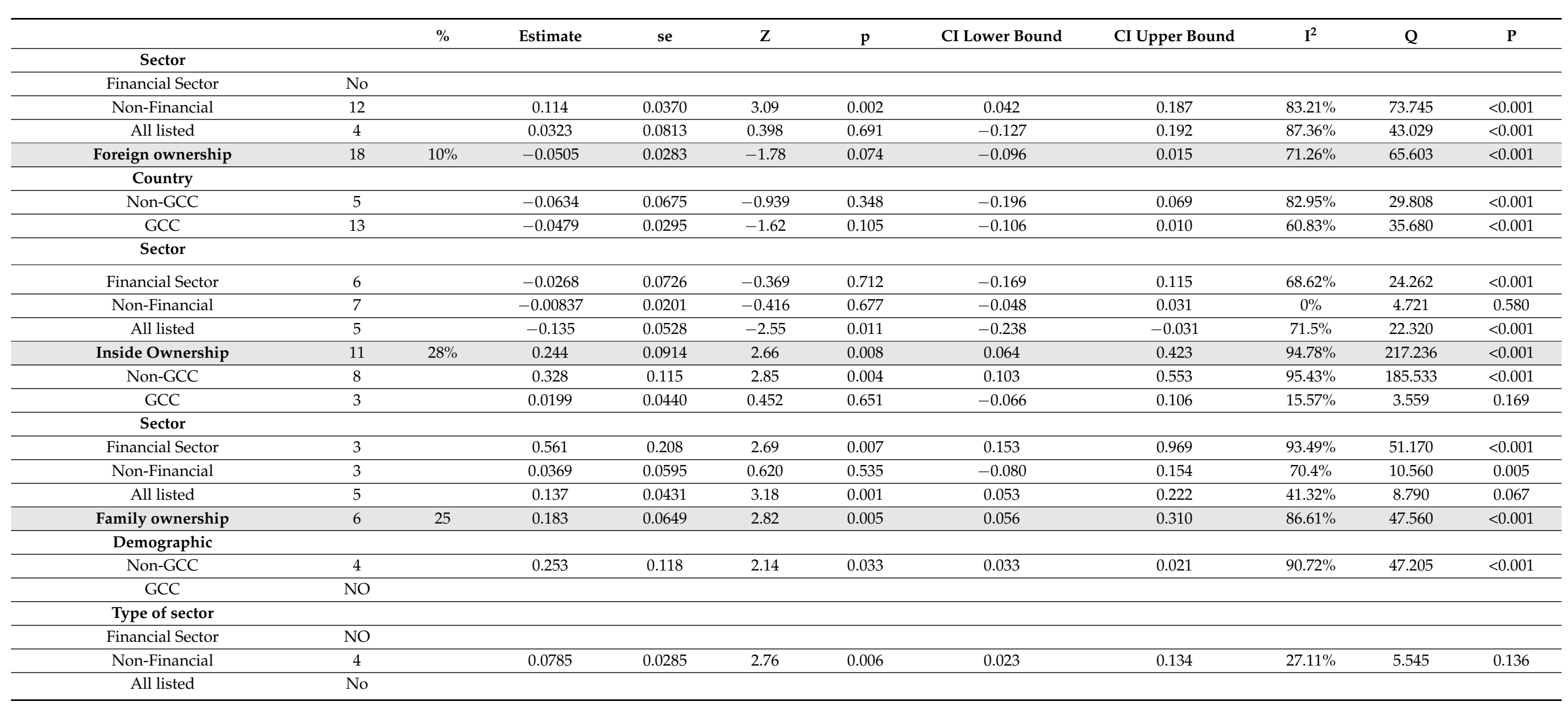


Table 3. Fixed effect size.

\begin{tabular}{|c|c|c|c|c|c|c|c|c|c|}
\hline & No. & Estimate & se & $\mathbf{Z}$ & $\mathbf{P}$ & $\begin{array}{l}\text { CI Lower } \\
\text { Bound }\end{array}$ & $\begin{array}{l}\text { CI Upper } \\
\text { Bound }\end{array}$ & $\mathbf{I}^{2}$ & $\mathbf{Q}$ \\
\hline Ow Concentration & 30 & 0.0159 & 0.0113 & 1.40 & 0.160 & -0.006 & 0.038 & $88.54 \%$ & $253.097 * * *$ \\
\hline Institutional Own & 24 & 0.0420 & 0.0120 & 4.35 & $<0.001$ & 0.029 & 0.075 & $49.1 \%$ & $45.187^{* * *}$ \\
\hline Government Ownership & 16 & 0.125 & 0.0123 & 10.1 & $<0.001$ & 0.101 & 0.149 & $87.39 \%$ & $118.950^{* * *}$ \\
\hline Foreign Ownership & 18 & -0.0627 & 0.0137 & -4.58 & $<0.001$ & -0.090 & -0.036 & $74.07 \%$ & $65.557^{* * *}$ \\
\hline Inside Ownership & 11 & 0.360 & 0.0163 & 22.1 & $<0.001$ & 0.328 & 0.392 & $97.53 \%$ & $404.382^{* * *}$ \\
\hline Family Ownership & 6 & 0.159 & 0.0211 & 7.55 & $<0.001$ & 0.118 & 0.200 & $94.83 \%$ & $96.706^{* * *}$ \\
\hline
\end{tabular}

The subgroups of the meta-analysis results are presented in Table 2. The results show that the two types of ownership concentration (shareholders that own $\geq 5 \%$ and the largest shareholders) do not have significant influence on the firm performance ( $Z=-1.10$; $p 0.270)$ and $(Z=1.61 ; p 0.106)$, respectively. When countries are classified into GCC and non-GCC, the association of the ownership concentration and firm performance remain insignificant. The result of the sector moderator shows that non-financial companies with concentrated ownership have better performance with a more significant positive result $(\mathrm{Z}=2.49 ; P$ 0.01) than financial companies in which the concentrated ownership has a negative yet insignificant effect $(Z=-0.794 ; \mathrm{P} 0.427)$. However, the magnitude of this effect in non-financial companies is modest, with a mean effect size of 0.08 . This result is consistent with the meta-analysis findings of Wang and Shailer (2015), who both found that concentrated ownership relation with performance is negative in the financial firms. Furthermore, their results found that the relationship between concentrated ownership and performance is negative in non-financial firms. These results contradict the results of this study. The difference magnitude of the effect of financial firms and non-financial firms on the concentrated ownership-performance relationship may be due to the different characteristics of each sector, such as accounting standards, ownership restrictions, or method of evaluation ratios. Generally, the result indicates that the largest shareholders in Middle Eastern countries do not practice control efficiently towards the increase in company performance. The absence of an effective role of concentrated ownership towards firm performance may be due to the weakness of regulations related to shareholders' rights in Middle Eastern countries. Bishara (2011) stated that Middle Eastern countries have poor regulations related to shareholder protections.

\subsection{Institutional Ownership}

Table 2 shows that the relationship between institutional ownership and firm performance has main correlations 0.0627 with $(\mathrm{Z}=3.51 ; p<0.001)$ and the confidence interval does not include zero (0.028 and 0.098), which indicates that institutional ownership has a highly positive significant impact on firm performance in Middle Eastern counties. Thus, hypothesis 2 is supported. However, the result of heterogeneity is significant $(Q=58.995$. $p<0.001)$, and the $\mathrm{I}^{2}$ test $(54.44 \%)$ indicated that there is heterogeneity, but at a moderate level. Comparing the level of heterogeneity to the variable of institutional ownership with the results of other variables of the ownership structure, institutional ownership has a low level of heterogeneity. However, the existence of heterogeneity across studies provides evidence for the possibility of existing moderator effects for the results of such a relationship. Thus, the investigation into the moderating variables is conducted to reduce the effect of heterogeneity. A meta-analysis of the sub-groups was conducted to investigate the moderating influence of the demographic factor and type of sector. The result shows that the role of institutional ownership in enhancing the company's performance remained 
significant in the non-GCC countries and even GCC countries with $(\mathrm{Z}=3.84 ; p<0.001$, and $Z=1.70 ; P 0.089$ ). In contrast, the relationship in the type of sector is significant in the non-financial companies and the listed companies alike. However, it is not significant in the financial companies. The insignificance of the role of institutional ownership in the financial companies can be interpreted as a result of the limited number of reviewed studies, namely only three studies. Generally, the result of the meta-analysis shows that institutional ownership plays a significant role in controlling companies and boosting the performance of companies in the Middle East. Furthermore, the magnitude of the power of institutional ownership in non-GCC countries is higher than GCC countries. This difference in magnitude may be due to the instability of political and economic situations in non-GCC countries. Thus, institutional owners attempt to get involved in controlling companies in order to protect their investment. This result is consistent with the finding of Mangena et al. (2012), who found that the ownership structure has a positive relationship with firm performance through political instability, while this relationship is negative in the political stability.

The significant impact of institutional ownership indicates that the institutional ownership positively contributes to improving the corporate performance in the Middle East. Institutional ownership in the Middle East plays an important role in monitoring, which reflects the corporate performance. The positive relationship between institutional ownership and performance is supported by the argument of Agency Theory, which postulates that shareholders' wealth can be maximized via separation between ownership and management. Furthermore, the finding is supported by Resource Dependence Theory, which assumes that institutional shareholders provide new sources and experience for the companies they invest in.

\subsection{Government Ownership}

The overall results of the meta-analysis are given in Table 2. The results indicate that government ownership is significantly positive with a corrected correlation of 0.0871 $(\mathrm{Z}=2.22 ; P 0.026)$ and a $95 \%$ confidence interval between 0.017 and 0.155 . The results show that hypothesis 3 is accepted. The positive relationship between government ownership and financial performance in the Middle East indicates that companies release good financial performance in the existence of increased government ownership. Furthermore, this positive association indicates that governments in the Middle East resort to using their power to control company management in order to secure good performance. Another justification is that involving governments in the ownership of publicly listed companies can build trust for investors and give companies the chance to make deals with government sectors. Al-Janadi et al. (2016) state that government ownership in the Middle East, as in the case of Saudi Arabia, heavily controls the listed companies. Furthermore, management feels that it operates in a friendly environment because of the reduced pressure it receives in the companies that have a high percentage of government ownership; this in turn is reflected in increased company performance. In addition, the positive relationship between government ownership and firm performance is consistent with the theoretical arguments of Jensen and Meckling (1979), who both argue that companies with a high percentage of government ownership can unanimously act on the interests between management and owners, which leads to increased firm performance.

For the heterogeneity test, the result shows that the parentage of variation across the studies is high, with an $\mathrm{I}^{2}$ of $89.4 \%$, which indicates that there are moderating factors that have an impact on this relationship. Further evidence of heterogeneity is the significance of $\mathrm{Q}$, which is $155.69(p>0.001)$. Therefore, the study further conducts the sub-group analysis to examine the impact of moderating factors.

The study splits the effect size of the overall sample (16) into two sub-groups: the demographic area (GCC and non-GCC) and the type of company sector (financial, nonfinancial, and all listed companies). The sub-group of the meta-analysis result of the demographic factor shows that the significance of the role of government ownership 
towards firm performance remained positive in GCC countries with an effect size of 0.108 $(Z=215 ; P 0.032)$, while this role was not significant in non-GCC countries $(Z=1.01$; $P$ 0.307). The insignificant result in non-GCC countries may be due to the limited number of studies (i.e., only five studies). The positive relationship between government ownership and performance in GCC countries may be due to the fact that governments in GCC countries have more power in the management control, which contributes to improving firm performance.

Furthermore, the type of government is monarchy in all GCC countries, while all nonGCC countries are republican. This type of political system could enhance the effective role of government ownership in practicing management control. Another justification is that most of the GCC governments have sufficient financial resources that enable companies to increase their chances of investments. This may reflect the increase in firm performance. This justification is in the same line with Roe (2006), who argues that companies with a strong government connection have privileges of gaining access to a wide range of varieties of resources. The political stability also plays a significant role in government ownership towards firm performance. In GCC countries, there is political stability in that the governments have the power of control while most non-GCC countries are politically unstable. Consequently, governments are neither willing to invest in the private sector nor able to control the management of companies. This justification is consistent with the Musibah (2017), who stated that political stability has a positive significant impact on the role of investors (e.g., foreign investment) in improving economic performance.

\subsection{Foreign Ownership}

The results of the meta-analysis in Table 2 show that foreign ownership has a negative relationship with performance. The effect size is $-0.05(Z=178 ; \mathrm{P} 0.074)$ with a confidence interval of $-0.096 / 0.015$. The inclusion of zero in the confidence interval indicates that this negative relationship is not significant. Thus, hypothesis 4 is rejected. Moreover, the test of heterogeneity $(\mathrm{Q}$ test) indicates that there is a high level of variance in the effect size (84.345 88; $p>0.001$ ). The insignificant relationship and rejection of the homogeneity test confirm the necessity to investigate the moderating factors affecting the result. Thus, the further sub-group analysis for the moderating variables is conducted to assess the distribution of the effect size.

The results of the sub-group meta-analysis in Table 2 incorporate two groups based on the demographic area (GCC countries vs. non-GCC countries) and the type of sectors (financial vs. non-financial, and all listed companies). The findings indicate that the relationship between foreign ownership and firm performance remained insignificant in both GCC countries $(r=-0.06)$ and non-GCC countries $(r=-0.0478)$. Similarly, the findings of the type of sector do not affect this relationship, except for a group of studies with all listed companies which enhance the negative relationship to be significant with an effect size -0.135 ( $Z=-2.55 ; \mathrm{P} 0.011)$. The negative significant impact of foreign ownership on performance, especially in the studies that targeted all listed companies, may be due to the large sample size. This is probably because studies with a larger sample size have a stronger impact from the increased weight of the effect size (Hunter and Schmidt 1990). Generally, foreign ownership does not play an important role in enhancing corporate performance. This insignificant role may be due to the low percentage (10\%) of ownership in Middle Eastern countries. Furthermore, regulation in the Middle East, especially some of GCC countries, still imposes restrictions on foreign investment. This indication is consistent with Zeitun (2014), who stated that foreign ownership faces legal restrictions such as risk management, portfolio investment, and diversification.

\subsection{Inside Ownership}

The result in Table 2 reports 11 studies for the relationship between inside ownership and firm performance. The inside ownership has a corrected coefficient of 0.244 with $\mathrm{Z}=2.66(P$ 0.008). As noted, a 95\% confidence interval is between 0.064 and 0.423 . This 
interval does not include zero, which indicates that inside ownership has a significant positive relationship with firm performance. Thus, hypothesis 5 is accepted. For the heterogeneity test, the $\mathrm{I}^{2}$ test shows a high percentage of variability in the effect size, with $94.78 \%$. The result of the $Q$ test $(217.236 ; p<0.001)$ also supports the existence of heterogeneity. Thus, the study conducted the moderating impact to reduce the heterogeneity in the estimated values. The result of the demographic location subgroup (GCC and non-GCC) reported that the relationship between inside ownership and firm performance remains significantly positive in non-GCC countries ( $\mathrm{r}: 0.328, \mathrm{Z}=2.66 ; p 0.004)$, while it is not significant in GCC countries. For the subgroup result related to the type of sector, Table 2 shows that the relationship of inside ownership with firm performance is positively significant in the financial sector and all listed companies group with $(Z=2.69 ; p 0.007)$ and $(Z=3.18 ; p 0.001)$, respectively. However, the result of this relationship is insignificant in the non-financial group $(\mathrm{Z}=0.620: p 0.535)$.

Generally, the finding of a positive significant of the ownership-performance relationship indicates that inside ownership acts in the interest of the companies. Thus, inside ownership can participate in saving and not abusing the resources of companies. This finding contributes to solving the agency problem by reducing the agency cost as the managers are owners (Jensen and Meckling 1976). Therefore, the managers will work together with other shareholders for the interest of the company because they are a part of it. Another justification is that inside owners play an effective role in enhancing firm performance, and this is probably due to the fact that they do not often represent other institutions. Therefore, the decisions they make are not influenced by the control of outside parties.

\subsection{Family Ownership}

Table 2 shows that there is a significant positive relationship between family ownership and firm performance with a corrected coefficient mean of 0.183 with $\mathrm{Z}=2.82(p 0.005)$. The confidence interval value is between 0.056 and 0.310 , which indicates that the relationship is significant; thus, hypothesis 6 is supported. In regard to the heterogeneity test, the result shows that the $Q$ test has a value of $47.560(p>0.001)$, which indicates that the heterogeneity is moderated. However, the $\mathrm{I}^{2}$ test indicates that heterogeneity is high, with $86.6 \%$. The result of heterogeneity is not very similar between the $\mathrm{Q}$ test and $\mathrm{I}^{2}$ test due to the small size of the sample. According to Higgins et al. (2003), Q has the power to test the existence of heterogeneity only if the sampling size is large. Thus, the $\mathrm{I}^{2}$ test is more accurate in testing the heterogeneity result because the construction of the $\mathrm{I}^{2}$ test is based on the non-central chi-square distribution method (Hedges and Pigott 2001). Owing to the existence of heterogeneity, the overall sample of family ownership is split into two sup-groups of moderating variables. The results of the meta-analysis of the subgroups in Table 2 show that the role of family ownership in enhancing firm performance remains positively significant in both non-GCC countries as one of the demographic moderators $(Z=2.14, p 0.033)$ and non-financial companies as one of the sector moderators $(Z=2.76$; $p$ 0.006). Despite the limited number of studies targeting family ownership in the Middle East, the result indicates that family ownership in Middle Eastern countries contributes to achieving higher performance. This achievement might be due to the family control of the board of directors, which results in a lower cost of agency. This statement is consistent with the argument of Agency Theory that a family member on the board can reduce the agency cost (Fama and Jensen 1983). Another indication of this positive impact may be due to the fact that most of the listed companies in the Middle East are family owned (Al-Janadi et al. 2016). Consequently, these families are still holding the control of the companies, and their incentives are directed towards the achievement of higher performance.

This study investigates the relationship between ownership concentration identities and firm performance using a fixed-effect model. The results in Table 3 based on a fixedeffect model show that most of the ownership concentration variables have a significantly positive relationship with firm performance. The variables institutional ownership, government ownership, family ownership, and inside ownership have a positive relationship with 
firm performance; foreign ownership is the only variable that has a negative relationship with firm performance. These results support our earlier discussion about the relationship which is based on the random effects model.

\section{Conclusions}

Middle Eastern countries are one the emerging markets that need to attract local and international investors to invest in the region. Attracting investors can enhance the capital market. Thus, investigating the current situation of ownership structure contributes to clarifying the role of different kinds of ownership towards the capital markets in the Middle East. This investigation also contributes to identifying the obstacles affecting the effectiveness of the shareholders' role. Knowing the obstacles and diagnosing the problems will contribute to finding appropriate ways to solve these problems. Furthermore, determining the size and the type of relationship between ownership structure variables and firm performance will contribute to understanding the reasons for this relationship. This understanding will help policymakers and other relevant parties to improve the role of different types of ownership in enhancing firm performance.

Using meta-analysis, the study investigated the impact of ownership structure variables on firm performance in the Middle East. The study also examined whether moderating variables such the type of sector and selection of countries have an influence on the relationship between ownership structure variables and firm performance. The major findings show that most of the ownership structure variables (institutional ownership, government ownership, inside ownership, and family ownership) have a significant positive relationship with firm performance, except for concentrated ownership and foreign ownership, which have a negative yet insignificant relationship. The results of the metaanalysis of the subgroups provide evidence that non-financial companies moderate the concentrated ownership relationship with firm performance to move from a negative relationship to a significant positive relationship, while non-financial companies weaken the role of inside ownership in enhancing firm performance. This weakness is due to the fact that, in non-financial companies, the concentrated ownership is high and has more control, which, in turn, weakens the role of inside ownership. This finding is consistent with the finding obtained by Perrini et al. (2008), who found that inside ownership has a positive relationship with firm performance in non-concentrated companies. The second subgroup of meta-analysis illustrates whether the demographic location has an influence on the strength of the relationship of ownership structure variables with firm performance. The study found that most of the ownership structure variables, such institutional ownership, foreign ownership, and inside ownership, practice their control in enhancing firm performance more effectively in non-GCC countries than GCC countries. In contrast, government ownership plays a positive role in increasing firm performance in GCC countries, while this role appears to be absent in non-GCC countries. The positive role of government ownership in GCC countries indicates that governments in GCC practice strong power in aligning the interests of shareholders with management, which reflects the increase in firm performance.

In regard to inside ownership, the findings of the study indicate that a high percentage of inside ownership in non-GCC countries motivates the positive relationship with firm performance. The active role of these ownership-structure variables in non-GGC countries is a result of weak regulation and political instability.

In connection with the results of the study, future research on the impact of political stability on the role of corporate governance mechanisms would provide a clear picture into the role of a control system with firm performance. Further future research could cover the relationship between ownership structure identities and voluntary disclosure.

Funding: This research received no external funding.

Institutional Review Board Statement: Not applicable.

Informed Consent Statement: Not applicable. 
Data Availability Statement: The data presented in this study were collected from the surveyed studies; these studies are listed in Table 1.

Acknowledgments: The author would like to thank the editor and three anonymous reviewers for their valuable comments.

Conflicts of Interest: The author declares no conflict of interest.

\section{References}

Abdallah, Abed Al-Nasser, and Ahmad K. Ismail. 2017. Corporate governance practices, ownership structure, and corporate performance in the GCC countries. Journal of International Financial Markets, Institutions and Money 46: 98-115. [CrossRef]

Abdelkarim, Naser, and Said Alawneh. 2009. The relationship between corporate governance and performance of palestinian firms: An empirical study. The International Journal of Business and Finance Research 3: 105-20.

Abobakr, Mohamed Galal. 2017. Corporate Governance and Banks Performance: Evidence from Egypt. Asian Economic and Financial Review 7: 1326-43. [CrossRef]

Abu-Serdaneh, Jamal, M. Zuriekat, and Imad Al-Sheikh. 2010. Ownership Structure and Corporate performance in the Jordanian manufacturing companies. Jordan Journal of Business Administration 6: 426-39.

Agrawal, Anup, and Charles R. Knoeber. 1996. Firm performance and mechanisms to control agency problems between managers and shareholders. Journal of Financial and Quantitative Analysis 31: 377-97. [CrossRef]

Aktan, Bora, Seref Turen, Manuela Tvaronavičienè, Saban Celik, and Hashem Abdullatif Alsadeh. 2018. Corporate governance and performance of the financial firms in Bahrain. Polish Journal of Management Studies 17: 39-58. [CrossRef]

Al-Ghamdi, Mohammed, and Mark Rhodes. 2015. Family ownership, corporate governance and performance: Evidence from Saudi Arabia. International Journal of Economics and Finance 7: 78-89. [CrossRef]

Al-Janadi, Yaseen, Rashidah Abdul Rahman, and Abdulsamad Alazzani. 2016. Does government ownership affect corporate governance and corporate disclosure? Managerial Auditing Journal 31: 871-90. [CrossRef]

Al-Malkawi, Husam-Aldin Nizar, and Rekha Pillai. 2018. Analyzing financial performance by integrating conventional governance mechanisms into the GCC Islamic banking framework. Managerial Finance 44: 604-23. [CrossRef]

Al-Matari, Ebrahim Mohammed, and A. S. Al-Arussi. 2016. The effect of the ownership structure characteristics on firm performance in Oman: Empirical study. Corporate Ownership and Control Journal 13: 93-100. [CrossRef]

Al-Matari, Ebrahim Mohammed, Yahya Ali Al-Matari, and Sulaiman Abdullah Saif. 2017. Association Between Ownership Structure Characteristics and Firm Performance: Oman Evidence. Academy of Accounting and Financial Studies Journal 21: 1-6.

Al-Saidi, Mejbel. 2013. Ownership Concentration and Firm Performance: The Case of Kuwait. Jordan Journal of Business Administration 153: 1-36. [CrossRef]

Al-Saidi, Mejbel, and Bader Al-Shammari. 2013. Board composition and bank performance in Kuwait: An empirical study. Managerial Auditing Journal 28: 472-94. [CrossRef]

Al-Saidi, Mejbel, and Bader Al-Shammari. 2015. Ownership concentration, ownership composition and the performance of the Kuwaiti listed non-financial firms. International Journal of Commerce and Management 25: 108-32. [CrossRef]

Al-Shammari, Bader, and Waleed Al-Sultan. 2009. Corporate Governance and Corporate Performance: Evidence from Kuwait. Corporate Ownership \& Control 7: 334-49.

Al-Shiab, Mohammad, and Abdussalam Abu-Tapanjeh. 2005. Ownership structure and firm performance: The case of Jordan. Journal of Business Administration 1: 1-27.

Al-Smadi, Mohammad O. 2013. Examining the relationship between corporate governance and banks' performance, and risk in Saudi Arabia. European Journal of Economics, Finance and Administrative Sciences 16: 59-62.

AlAni, Mawih Kareem, and Asma Mohammed AlKathiri. 2019. Ownership concentration and firm performance: An empirical analysis in Oman. The European Journal of Applied Economics 16: 79-94.

Alawi, Suha. 2019. Relationship between Capital Requirement, Ownership Structure, and Financial Performance in Saudi Arabian Listed Companies. Asian Economic and Financial Review 9: 1077. [CrossRef]

Alfaraih, Mishari, Faisal Alanezi, and Hesham Almujamed. 2012. The influence of institutional and government ownership on firm performance: Evidence from Kuwait. International Business Research 5: 192-200. [CrossRef]

Almazan, Andres, Jay C. Hartzell, and Laura T. Starks. 2005. Active institutional shareholders and costs of monitoring: Evidence from executive compensation. Financial Management 34: 5-34. [CrossRef]

Almudehki, Noora, and Rami Zeitun. 2012. Ownership Structure and Corporate Performance: Evidence from Qatar. Available online: http:/ / ssrn.com/abstract=2154289 (accessed on 23 December 2020).

AlSagr, Naif, Samir Belkhaoui, and Abdullah Aldosari. 2018. The Effect of Corporate Governance Mechanisms on Bank Performance Evidence from Saudi Banking Sector. Asian Economic and Financial Review 8: 1111-25. [CrossRef]

Amin, Anisa Abdulrahman, and Allam Mohammed Hamdan. 2018. Evaluating the Effect of Ownership Structure on Firm Performance: Evidence from Saudi Arabian Listed Companies. Journal of Economic Cooperation E Development 39: 65-92.

Anderson, Ronald C., and David M. Reeb. 2003. Founding-family ownership and firm performance: Evidence from the S\&P 500. The Journal of Finance 58: 1301-28. 
Arayssi, Mahmoud, and Mohammad Issam Jizi. 2018. Does corporate governance spillover firm performance? A study of valuation of MENA companies. Social Responsibility Journal 15: 597-620. [CrossRef]

Arouri, Houda, Mohammed Hossain, and Mohammad Badrul Muttakin. 2011. Ownership structure, corporate governance and bank performance: Evidence from GCC countries. Corporate Ownership and Control 8: 365-72. [CrossRef]

Arouri, Houda, Mohammed Hossain, and Mohammad Badrul Muttakin. 2014. Effects of board and ownership structure on corporate performance: Evidence from GCC countries. Journal of Accounting in Emerging Economies 4: 117-30. [CrossRef]

Barbosa, Natália, and Helen Louri. 2005. Corporate performance: Does ownership matter? A comparison of foreign-and domesticowned firms in Greece and Portugal. Review of Industrial Organization 27: 73-102. [CrossRef]

Basuony, Mohamed, K. A. Ehab, and Dr Al-Baidhani. 2014. The effect of corporate governance on bank financial performance: Evidence from the Arabian Peninsula. Corporate Ownership \& Control 11: 178-91.

Benfratello, Luigi, and Alessandro Sembenelli. 2002. Research joint ventures and firm level performance. Research Policy 31: 493-507. [CrossRef]

Bishara, Norman D. 2011. Governance and corruption constraints in the Middle East: Overcoming the business ethics glass ceiling. American Business Law Journal 48: 227-83. [CrossRef]

Bocatto, Eduardo, Carles Gispert, and Josep Rialp. 2010. Family-owned business succession: The influence of pre-performance in the nomination of family and nonfamily members: Evidence from Spanish firms. Journal of Small Business Management 48: 497-523. [CrossRef]

Borenstein, Michael, Larry V. Hedges, Julian P.T. Higgins, and Hannah R. Rothstein. 2009. Introduction to Meta-Analysis. Hoboken: John Wiley \& Sons, ISBN 9780470057247.

Boycko, Maxim, Andrei Shleifer, and Robert W. Vishny. 1996. A theory of privatisation. The Economic Journal 106: 309-19. [CrossRef]

Carney, Michael, and Eric Gedajlovic. 2001. Corporate governance and firm capabilities: A comparison of managerial, alliance, and personal capitalisms. Asia Pacific Journal of Management 18: 335-54. [CrossRef]

Chaddad, Fabio R., and Michael L. Cook. 2004. Understanding new cooperative models: An ownership-control rights typology. Applied Economic Perspectives and Policy 26: 348-60. [CrossRef]

Charbel, Salloum, Bouri Elie, and Samara Georges. 2013. Impact of family involvement in ownership management and direction on financial performance of the Lebanese firms. International Strategic Management Review 1: 30-41. [CrossRef]

Claessens, Stijn, Joseph P.H. Fan, and Larry H.P. Lang. 2006. The benefits and costs of group affiliation: Evidence from East Asia. Emerging Markets Review 7: 1-26. [CrossRef]

Claessens, Stijn, Simeon Djankov, Joseph P.H. Fan, and Larry H.P. Lang. 2002. Disentangling the incentive and entrenchment effects of large shareholdings. The Journal of Finance 57: 2741-71. [CrossRef]

Cochran, William G. 1954. The combination of estimates from different experiments. Biometrics 10: 101-29. [CrossRef]

Coffee, John C. 1991. Liquidity versus control: The institutional investor as corporate monitor. Columbia Law Review 91: 1277-368. [CrossRef]

Cook, Michael L. 1995. The future of US agricultural cooperatives: A neo-institutional approach. American Journal of Agricultural Economics 77: 1153-59. [CrossRef]

Cooper, Harris, Larry V. Hedges, and Jeffrey C. Valentine. 2019. The Handbook of Research Synthesis and Meta-Analysis. New York: Russell Sage Foundation, ISBN 978-0-87154-163-5.

Dalwai, Tamanna Abdul Rahman, Rohaida Basiruddin, and Siti Zaleha Abdul Rasid. 2015. A critical review of relationship between corporate governance and firm performance: GCC banking sector perspective. Corporate Governance 15: 18-30. [CrossRef]

Demsetz, Harold, and Kenneth Lehn. 1985. The structure of corporate ownership: Causes and consequences. Journal of Political Economy 93: 1155-77. [CrossRef]

Denis, David J., and Diane K. Denis. 1994. Majority owner-managers and organizational efficiency. Journal of Corporate Finance 1: 91-118. [CrossRef]

Denis, Diane K., and John J. McConnell. 2003. International corporate governance. Journal of Financial and Quantitative Analysis 38: 1-36. [CrossRef]

Desoky, Abdelmohsen M., and Gehan A. Mousa. 2013. An empirical investigation of the influence of ownership concentration and identity on firm performance of Egyptian listed companies. Journal of Accounting in Emerging Economies 3: 164-88. [CrossRef]

Douma, Sytse, Rejie George, and Rezaul Kabir. 2006. Foreign and domestic ownership, business groups, and firm performance: Evidence from a large emerging market. Strategic Management Journal 27: 637-57. [CrossRef]

Dwaikat, Nizar, and Abdelbaset Queiri. 2014. The Relationship between Ownership Structure and Firm's Performance: An Empirical Evidence from Palestine. International Journal of Business and Management 9: 49-61. [CrossRef]

Eisenhardt, Kathleen M. 1989. Agency theory: An assessment and review. Academy of Management Review 14: 57-74. [CrossRef]

El-Chaarani, Hani. 2014. The impact of corporate governance on the performance of Lebanese banks. The International Journal of Business and Finance Research 8: 35-46.

Elghuweel, Mohamed I., Collins G. Ntim, Kwaku K. Opong, and Lynn Avison. 2017. Corporate governance, Islamic governance and earnings management in Oman: A new empirical insights from a behavioural theoretical framework. Journal of Accounting in Emerging Economies 7: 190-224. [CrossRef]

Eljelly, Abuzar M.A. 2009. Ownership and firm performance: The experience of Saudi Arabia's emerging economy. International Business E Economics Research Journal 8: 25-34. 
Ellis, Paul D. 2010. The essential Guide to Effect Sizes: Statistical Power, Meta-Analysis, and the Interpretation of Research Results, 6th ed. Cambridge: Cambridge University Press.

Elsayed, Khaled. 2007. Does CEO duality really affect corporate performance? Corporate Governance: An International Review 15: 1203-14. [CrossRef]

Epps, Ruth W., and Sandra J. Cereola. 2008. Do institutional shareholder services (ISS) corporate governance ratings reflect a company's operating performance? Critical Perspectives on Accounting 19: 1135-48. [CrossRef]

Fallatah, Yaser. 2015. CEO compensation, firm performance and corporate governance, an empirical investigation of Saudi Arabian companies. Management Research Report 3: 43-71.

Fama, Eugene F., and Michael C. Jensen. 1983. Separation of ownership and control. The Journal of Law and Economics 26: 301-25. [CrossRef]

Gillan, Stuart L. 2006. Recent developments in corporate governance: An overview. Journal of Corporate Finance 12: 381-402. [CrossRef]

Grashuis, Jasper, and Ye Su. 2019. A review of the empirical literature on farmer cooperatives: Performance, ownership and governance, finance, and member attitude. Annals of Public and Cooperative Economics 90: 77-102. [CrossRef]

Grossman, Sanford J., and Oliver D. Hart. 1980. Takeover bids, the free-rider problem, and the theory of the corporation. The Bell Journal of Economics, 42-64. [CrossRef]

Haider, Zulfiquer Ali, Mingzhi Liu, Yefeng Wang, and Ying Zhang. 2018. Government ownership, financial constraint, corruption, and corporate performance: International evidence. Journal of International Financial Markets, Institutions and Money 53: 76-93. [CrossRef]

Hamdan, Allam. 2018. Board interlocking and firm performance: The role of foreign ownership in Saudi Arabia. International Journal of Managerial Finance 14: 266-81. [CrossRef]

Hedges, Larry V., and Ingram Olkin. 1985. Statistical Methods for Meta-Analysis. Orlando: Academic Press, Inc.

Hedges, Larry V., and Therese D. Pigott. 2001. The power of statistical tests in meta-analysis. Psychological Methods 6: 203. [CrossRef]

Heugens, Pursey PMAR, Marc Van Essen, and J. Hans van Oosterhout. 2009. Meta-analyzing ownership concentration and firm performance in Asia: Towards a more fine-grained understanding. Asia Pacific Journal of Management 26: 481-512. [CrossRef]

Higgins, Julian PT, Simon G. Thompson, Jonathan J. Deeks, and Douglas G. Altman. 2003. Measuring inconsistency in meta-analyses. BMJ 327: 557-60. [CrossRef]

Hillman, Amy J., and Thomas Dalziel. 2003. Boards of directors and firm performance: Integrating agency and resource dependence perspectives. Academy of Management Review 28: 383-96. [CrossRef]

Hunter, John E., and Frank L. Schmidt. 1990. Dichotomization of continuous variables: The implications for meta-analysis. Journal of Applied Psychology 75: 334-49. [CrossRef]

Hunter, John E., and Frank L. Schmidt. 2004. Methods of Meta-Analysis: Correcting Error and Bias in Research Findings, 2nd ed. Thousand Oaks: Sage Publications, Inc.

Jaafar, Aziz, and Mahmoud El-Shawa. 2009. Ownership concentration, board characteristics and performance: Evidence from Jordan. Accounting in Emerging Economies 9: 73-95.

Jadah, Hamid Mohsin, Murugiah Logasvathi, and Azira Abdul Adzis. 2016. The Joint Effect of Ownership Structure on Bank Financial Performance: Empirical Evidence from Iraq. International Journal of Research in Management, Economics and Commerce 6: 46-52.

Jensen, Michael C., and Jerold B. Warner. 1988. The distribution of power among corporate managers, shareholders, and directors. Journal of Financial Economics 20: 3-24. [CrossRef]

Jensen, Michael C., and William H. Meckling. 1976. Theory of the firm: Managerial behavior, agency costs and ownership structure. Journal of Financial Economics 3: 305-60. [CrossRef]

Jensen, Michael C., and William H. Meckling. 1979. Rights and production functions: An application to labor-managed firms and codetermination. Journal of Business 52: 469-506. [CrossRef]

Khamis, Reem, Wajeeh Elali, and Allam Hamdan. 2015. Ownership structure and corporate financial performance in Bahrain bourse. Corporate Ownership and Control 13: 413-34. [CrossRef]

Kisamore, Jennifer L., and Michael T. Brannick. 2008. An illustration of the consequences of meta-analysis model choice. Organizational Research Methods 11: 35-53. [CrossRef]

La Porta, Rafael, Florencio Lopez-de-Silanes, and Andrei Shleifer. 1999. Corporate ownership around the world. The Journal of Finance 54: 471-517. [CrossRef]

La Porta, Rafael, Florencio Lopez-de-Silanes, Andrei Shleifer, and Robert W. Vishny. 1998. Law and finance. Journal of Political Economy 106: 1113-55. [CrossRef]

La Porta, Rafael, Florencio Lopez-de-Silanes, Andrei Shleifer, and Robert W. Vishny. 2002. Investor protection and corporate valuation. The Journal of Finance 57: 1147-70. [CrossRef]

Laffont, Jean-Jacques, and Jean Tirole. 1991. The politics of government decision-making: A theory of regulatory capture. The Quarterly Journal of Economics 106: 1089-127. [CrossRef]

Lefort, Fernando, and Francisco Urzúa. 2008. Board independence, firm performance and ownership concentration: Evidence from Chile. Journal of Business Research 61: 615-22. [CrossRef]

Luo, Yadong. 2007. Global Dimensions of Corporate Governance. Malden: Wiley-Blackwell Publishing.

Makhlouf, Mohammed Hassan, N. H. Laili, N. A. Ramli, and M. Y. Basah. 2017. Board of Directors' Effectiveness and Firm Performance: Evidence from Jordan. Research Journal of Finance and Accounting 8: 23-34. 
Mangena, Musa, Venancio Tauringana, and Eddie Chamisa. 2012. Corporate boards, ownership structure and firm performance in an environment of severe political and economic crisis. British Journal of Management 23: S23-S41. [CrossRef]

Maug, Ernst. 1998. Large shareholders as monitors: Is there a trade-off between liquidity and control? The Journal of Finance 53: 65-98. [CrossRef]

McConnell, John J., and Henri Servaes. 1990. Additional evidence on equity ownership and corporate value. Journal of Financial Economics 27: 595-612. [CrossRef]

Mohammed, Ahmed Maqsad. 2018. The Impact of Ownership Structure on Firm Performance: Evidence from Jordan. Academy of Accounting and Financial Studies Journal 22: 1-9.

Morck, Randall, Andrei Shleifer, and Robert W. Vishny. 1988. Management ownership and market valuation: An empirical analysis. Journal of Financial Economics 20: 293-315. [CrossRef]

Morck, Randall, Daniel Wolfenzon, and Bernard Yeung. 2005. Corporate governance, economic entrenchment, and growth. Journal of Economic Literature 43: 655-720. [CrossRef]

Musibah, Anwar Salem. 2017. Political stability and attracting foreign direct investment: A comparative study of Middle East and North African Countries. Science International-Lahore 29: 679-83.

Perrini, Francesco, Ginevra Rossi, and Barbara Rovetta. 2008. Does ownership structure affect performance? Evidence from the Italian market. Corporate Governance: An International Review 16: 312-25. [CrossRef]

Pfeffer, Jeffrey, and Gerald R. Salancik. 2003. The External Control of Organizations: A Resource Dependence Perspective. Palo Alto: Stanford University Press.

Piesse, Jenifer, Roger Strange, and Fahad Toonsi. 2012. Is there a distinctive MENA model of corporate governance? Journal of Management \& Governance 16: 645-81.

Qasim, Amer Mohammed Jaser, and Amer Mohammad. 2014. The Impact of Corporate Governance on Firm Performance: Evidence from the UAE. European Journal of Business and Management 6: 118-24.

Roe, Mark J. 2006. Political Determinants of Corporate Governance: Political Context, Corporate Impact, 1st ed. Oxford: Oxford University Press.

Santiago-Castro, Marisela, and Cynthia J. Brown. 2007. Ownership structure and minority rights: A Latin American view. Journal of Economics and Business 59: 430-42. [CrossRef]

Sarhan, Ahmed A., Collins G. Ntim, and Basil Al-Najjar. 2018. Board diversity, corporate governance, corporate performance, and executive pay. International Journal of Finance $\mathcal{E}$ Economics 24: 761-86.

Shawtari, Fekri Ali Mohammed. 2018. Ownership type, bank models, and bank performance: The case of the Yemeni banking sector. International Journal of Productivity and Performance Management 67: 1271-89. [CrossRef]

Shleifer, Andrei, and Robert W. Vishny. 1986. Large shareholders and corporate control. Journal of Political Economy 94: 461-88. [CrossRef]

Shleifer, Andrei, and Robert W. Vishny. 1997. A survey of corporate governance. The Journal of Finance 52: 737-83. [CrossRef]

Smith, Brian F., and Ben Amoako-Adu. 1999. Management succession and financial performance of family controlled firms. Journal of Corporate Finance 5: 341-68. [CrossRef]

Smith, P. A. 2009. Gulf aims to take lead in corporate governance. Middle East 396: 52-56.

Soliman, Mohammed. 2013. Ownership Concentration and Firm Financial Performance-Evidence from Saudi Arabia. Available online: https: / / papers.ssrn.com/sol3/papers.cfm?abstract_id=2257832 (accessed on 14 July 2021).

Talab, Hassnain Raghib, Kamarul Bahrain Abdul Manaf, and Siti Seri Delima Abdul Malak. 2018. Ownership Structure, External Audit and Firm Performance in Iraq. Social Science and Humanities Journal, 343-53.

Walsh, James P., and James K. Seward. 1990. On the efficiency of internal and external corporate control mechanisms. Academy of Management Review 15: 421-58. [CrossRef]

Wang, Kun Tracy, and Greg Shailer. 2015. Ownership concentration and firm performance in emerging markets: A meta-analysis. Journal of Economic Surveys 29: 199-229. [CrossRef]

Wang, Kun Tracy, and Greg Shailer. 2017. Family ownership and financial performance relations in emerging markets. International Review of Economics E Finance 51: 82-98.

Williamson, Oliver E. 1991. Comparative economic organization: The analysis of discrete structural alternatives. Administrative Science Quarterly, 269-96. [CrossRef]

Yilmaz, Ilker. 2018. Corporate governance and financial performance relationship: Case for Oman companies. Journal of Accounting, Finance and Auditing Studies 4: 84-106. [CrossRef]

Yu, Guanghua, and Li Shao. 2007. Against legal origin: Of ownership concentration and disclosure. Journal of Corporate Law Studies 7: 285-305. [CrossRef]

Zeckhauser, Richard J., and John Pound. 1990. Are large shareholders effective monitors? An investigation of share ownership and corporate performance. In Asymmetric Information, Corporate Finance, and Investment. Edited by Glenn Hubbard. Chicago: University of Chicago Press, vol. 1, pp. 149-80.

Zeitun, Rami. 2012. Determinants of Islamic and conventional banks performance in GCC countries using panel data analysis. Global Economy and Finance Journal 5: 53-72.

Zeitun, Rami. 2014. Corporate governance, capital structure and corporate performance: Evidence from GCC countries. Review of Middle East Economics and Finance. 10: 75-96. [CrossRef] 
Zeitun, Rami, and Gary Gang Tian. 2007. Does ownership affect a firm's performance and default risk in Jordan? Corporate Governance: The International Journal of Business in Society 7: 66-82. [CrossRef]

Zraiq, Mohammad Ahmad Abu, and Faudziah Hanim Bt Fadzil. 2018. The impact of ownership structure on firm performance: Evidence from Jordan. International Journal of Accounting, Finance and Risk Management 3: 1-4. [CrossRef] 